\title{
Construction of Teaching Team Based On the Improvement of Teaching Quality of Automobile Service Engineering
}

\author{
Yinqiao Gao \\ Guangdong University of Science and Technology, Dongguan, Guangdong, China \\ 441089188@qq.com
}

Keywords: Applied undergraduate; Teaching quality; "Double-Qualified" teachers; Teaching team construction

\begin{abstract}
Characteristic Education is the Competition Core of Application - oriented Universities. Building a team of "double-qualified" teachers with strong personnel, good quality, reasonable structure, special combination, innovative spirit and relative stability, is the key to improve the teaching quality of application-oriented colleges, the key of their survival and development, and the fundamental guarantee of their education quality. The article takes application - oriented undergraduate course of automobile service engineering as an example to discuss the connotation, characteristics, function and approach of teaching team construction based on professional education and teaching quality promotion.
\end{abstract}

\section{Introduction}

Applied undergraduate talents training goal is to transport high-quality social "high-skilled complex" talent. Taking automobile service engineering as an example, with the rapid development of China's automobile service industry, society needs a large number of automotive service professionals. Therefore, the applied undergraduate automotive service engineering professional training objectives are: to cultivate both a solid knowledge of mechanical science and deep knowledge of automotive technology, but also to master the necessary production management, marketing, financial insurance and claims, vehicle maintenance services and other aspects of the theory, which has a strong engineering quality and innovative spirit, but also has a strong automotive service engineering expertise, and good organizational management capabilities, capable of automotive production services, car sales services, automotive technology services, automotive financial services and other fields of work, the "multi-skill" of the application of compound talents. In order to achieve the above-mentioned training objectives, it is necessary to set up their own professional knowledge system, teaching content, curriculum model, teaching methods and teaching team to meet the needs of improving the quality of education and teaching, and the first four indicators can be implemented, the key to rely on human factors - the role of teaching team play. In other words, in the construction of education and teaching quality improvement project, strengthen the construction of professional teaching team, from the overall professional teaching team to improve teaching ability and teaching level, is the implementation of "quality engineering and innovation strong school project", the key to improve professional Teaching quality level.

\section{Teaching Team's Connotation and Characteristics}

Teaching team is taking teaching as the main line, with professional construction, curriculum construction, teaching materials construction, experimental and practical base construction, teaching and research as the focus, to promote teaching reform, improve teaching quality as the main task, taking college, department, teaching and research section as the construction unit, to produce teaching and research and other aspects of the complementary advantages of the core team of teachers. Under normal circumstances, professional teaching team should have the following five characteristics:

Have a Clear Goal of Teaching Construction. As to the task demand of application - oriented 
universities, the teaching team is composed of teachers who are responsible for teaching reform and teaching quality improvement, and mutual responsibility for common teaching reform. Therefore, the establishment of professional teaching team should have a clear goal of the development of teaching construction, teaching team should take professional construction, curriculum construction, teaching materials construction and teaching practice base construction and other teaching infrastructure projects as the carrier, to carry out teaching research, teaching reform, planning, phased to improve the teaching team's teaching level and quality of personnel training. And its teaching team should be in the school, provincial and national characteristics of professional construction, quality course construction, excellent teaching materials construction and practice teaching reform project fully play its role. [1]

Have a Clear Direction of Teaching Reform. Teaching team building should keep up with the trend of the exhibition, accurately grasp the direction of professional construction and teaching reform, timely update the content of teaching, and guide students to innovative learning and innovative experiments, and continuously improve the quality of professional teaching. In the popularization of higher education today, compared with the needs of teaching and research talents, the society needs more applied talents, while the traditional undergraduate talent cultivation system emphasizes the integrity of the basic knowledge teaching and theoretical system, ignoring the application ability building, "Heavy theory, light practice" tendency, is not conducive to the cultivation of applied talents. [2] Specific to the application of undergraduate automotive service engineering professional terms, they have to develop personnel training programs according to the development trend and demand of the industry to, reform the training mode, strengthen professional connotation construction, and establish teaching content and methods, in order to highlight the professional characteristics, industry characteristics and application characteristics.

Have a Reasonable Teaching Echelon. Reasonable teaching echelon is the foundation of forming and building the excellent teaching team. To make full use of the quality resources of the teaching team, the members of the teaching team should be optimized in the aspects of age structure, education structure, academic structure and title structure. Teaching team should be led by the leader of teaching, learning and research team, with the backbone of young teachers as the main body, formed by professors, associate professors, lecturers, teaching assistants and teaching staff, composed of echelon reasonable talent, which have teaching experience, teaching effect excellent teachers, and strong scientific capacity of teaching and research backbones, as well as teaching staff with rich practical experience and strong practice ability.

Have Excellent Teaching Construction Achievements. Excellent teaching construction achievements are the indicators of the effectiveness of the teaching team construction. The construction of professional teaching team should be reflected in the aspects of teachers' teaching level, teaching effect and quality of personnel training. In the specific teaching research and reform projects should be made at the school level, provincial or national landmark results, such as teaching achievement awards, quality courses, characteristic or demonstration specialties, experimental teaching and research section, or show a good trend to obtain excellent results. [3]

Have Excellent Teaching Research Results. Professional teaching team should actively combine the industry and enterprise production to carry out teaching and research work. Outstanding teachers with high level of teaching, quite accomplished in research, should play the leading role of teaching, leading young teachers to actively carry out scientific research, and strive to obtain teaching and research results, and can put the latest research results into the teaching field, effectively promote the reform of teaching content, methods and means, and improve the teaching quality.

\section{The Effect of Teaching Team Construction on Improving Teaching Quality}

Quality is the lifeline of colleges and universities, teaching is the functional work of colleges and universities, teaching team building is the key to improve the quality of teaching. [4]

Promote the Overall Quality of Teachers. Improve the quality of teaching depends on the overall quality of teachers. In the construction of teaching team, the teaching masters lead the 
professional leaders, play the role of inspiration, support team members, especially young teachers to go to domestic and foreign well-known universities to visit for further study, actively carry out mentoring and other forms of aid activities, promote teaching research and teaching experience exchange, in order to achieve the combination of old and young, and continuously improve young teachers' teaching level and sense of responsibility, to truly cultivate young teachers to be the backbone of teaching work, and strive to cultivate a reasonable structure, higher level of backbone young team, to promote the overall quality of teachers. [5]

Promote the Teaching Talents (National Teachers, Provincial Teachers and Backbone Teachers) Growth. Teaching masters, professional leaders and other senior team members in teaching team should be as much as possible in-depth first-line teaching, professional commitment to teaching, so that students enjoy the best quality teaching resources, professors play a more active role in teaching activities, to maximize the enthusiasm of team members' initiative and creativity in teaching practice and teaching reform, can not only to improve the quality of professional teaching, but also provide a good soil for teaching top-notch talent and the backbone teachers' growth.

Promote Students' Practice and Innovation Ability. The improvement of students' practical ability and innovation ability is the basic goal of the teaching team in practice teaching. It is the foundation to promote the teaching quality of applied undergraduate course and cultivate applied talents. It is also the platform of innovative practice teaching. Taking automotive service engineering as an example, the teaching team's teaching reform objectives and personnel training program formulation, should be on the development of the automotive industry, business development of talent knowledge, quality, ability structure needs, to cultivate students' apply ability, learning ability and innovation ability as the gist, draw lessons from the successful experience of higher education in developed countries, determine the training objectives, design talent training specifications, develop personnel training programs, select the way of personnel training. [6] And through experiment and practice base construction, cultivate college students to carry out scientific experiments and social practice, and guide students to actively participate in teaching production and research activities to achieve the best combination of theoretical teaching and practical teaching, cultivate students' practical ability and independent innovation ability.

Promote Teaching Methods, Teaching Content Reform. Teaching reform is the main task of teaching team construction. In the practice of "quality engineering education" and "innovation engineering education", different types of universities have different orientation and development direction. Even if the specialty is the same, the orientation and cultivation mode is not the same, application-oriented undergraduate training is able to apply scientific theories and methods to solve practical problems or engaged in applied research of high-level application-oriented talents. [7] For example, application-oriented undergraduate automotive service engineering teaching team, not only to have a solid professional theoretical knowledge, but also should have the ability to impart these professional knowledge to students; not only skilled proficiency in the industry, should have this skill to guide the practice of students, is to use the most effective teaching methods, the latest teaching results, so that students access to new knowledge and skills, and promote the comprehensive development of students, to cultivate a large number of practical talents for regional economic development and industry enterprises.

\section{Approach to the Construction of "Double-Qualified" Teachers}

The construction of "double - qualified" professional teachers is an inevitable requirement of educational reform and development. It is necessary to build a teaching team of "double teachers" who can teach students how to understand technology, operation and application, so as to cultivate the first - line talents of production, construction, management and service in application - oriented colleges and universities.

The Basic Characteristics of "Double-Qualified" Teachers. "Double-qualified" teachers refer to teachers who have high moral character, strong teaching ability, rich practical experience and strong professional demonstrative operation ability and strong scientific research ability. These abilities are realized in the process of repeated blending between theory and practice. At the same 
time, these abilities also need to meet the relevant professional skill appraisal standards. Only teachers who meet these conditions can be called "double - qualified" teachers. Taking the automotive service engineering for example, its professional teachers should not only have rich theoretical knowledge of the automotive industry, should have a wealth of practical experience and experience in the automotive industry, understand the technology, operation, application, not just empty talk. The former Minister of State Education Zhou Ji also pointed out: in accordance with the requirements of market economy to promote the openness and diversity of vocational education, the focus is to implement the combination of production and education, school-enterprise cooperation, strengthening the construction of double-qualified teachers. [8]

The Formation of "Double-Qualified" Teachers. School-enterprise cooperation, production-teaching-research combination is an effective way to construct the "double - qualified" professional teachers in application oriented universities. The mechanism of application undergraduate colleges is flexible, and the cooperation between schools and enterprises is of great advantage in the construction of "double - qualified" teachers. Especially in institutions that set up applied undergraduate automotive service engineering specialties after 2010, young teachers are in the majority, most of them are made in the traditional research-based personnel training mode, from school to school, from classroom to classroom. They are rich in theoretical knowledge, but lack of practical experience. It is takes time to grow up. But these teachers are energetic, and have strong ability to accept new things. Through school-enterprise cooperation, we can achieve integration of teaching and research, turn the cooperative enterprise into a stable "double - qualified" teacher training base, arrange them into the industry, enterprises, scientific research units to carry out attachment training, bring the enterprise projects into classroom teaching, hire enterprise teachers into classroom, to create mutual benefit and win-win cooperation system, so as to promote the application-oriented colleges and universities professional teachers' practical skills and technology development abilities. [9] At the same time, it is also an effective way to improve the practical teaching ability of applied undergraduate colleges' teachers by building practical training centers and practice factories to improve the young teachers' practical ability.

The Scientific Management of "Double-Qualified" Teachers. Good humane environment is an important factor to attract teachers, establishing scientific evaluation system is an effective way to carry out scientific management, in practice, different schools should introduce democratic principles into teachers management, at the same time of establishing and perfecting management system, attention to the cause of cohesion, with discipline education, with a good environment to keep a man, to motivate people to develop goals. Advocate the implementation of quantitative management and emotional penetration of combining the management mode, process management and "humane" management; emphasize the "three prominent" in the management process, which is, highlighting the status and role of teachers, highlighting the respect and understanding of the teachers, emphasizing the management of human resources management, highlighting the development and promotion of teachers. [10]

\section{Concluding Remarks}

As an integral part of socialist education, application - oriented colleges have made leaps and bounds in the scale and level of education so as to cultivate a large number of high - quality skilled talents for regional economic development. In the current situation, the application-oriented universities are in the critical period of development. The key to the construction of "double qualified" teachers in application-oriented universities is to improve the technical application ability and practical ability of young teachers. Sustainable development of the excellent "double qualified" teachers, should be able to timely insight into the development of forecasting industry changes to capture the job market demand for talent; should understand the application of the special laws of undergraduate education, timely reform of professional teaching plan, adjust Professional curriculum, to achieve education closely follow the socio-economic development, personnel training and market demand for talent closely. 


\section{References}

[1] Opinions of the State Council on Strengthening the Construction of Teaching Staff. Promulgated by the State Council, No. 41, 2012

[2] National Long-Term Education Reform and Development Plan (2010-2020)

[3] Opinions of the People's Government of Guangdong Province on the Full Implementation of "Strong Teacher Project" and the Construction of High - quality and Specialized Teaching Staff. Gazette of the People's Government of Guangdong Province, 2012 (25), p.45

[4] Z. L. Gao, Z. F. Li: Journal of Zhejiang Water Conservancy and Hydropower College, (2013) No.4, p.71

[5] X. X. Liu: the Sea buckthorn: Science and Education, (2010) No.11, p.51

[6] M. L. Pan: the Guangdong Education: Comprehensive Edition, (2012) No.10, p.20

[7] J. C. Lai: the Guangdong Education: Vocational Education, (2012) No.9, p.4

[8] J. H. Liu, J. Q. Liu: Economic Study Guide, (2009) No.5, p.234

[9] Y. P. Xie: The Research on Teaching Team-Building in University (MS, Hunan University, China, 2010).p.39

[10] J. Liu: On Developing Dual Qualification Teacher Programming in Higher Vocational Colleges: A Case of Guangdong Institute of Science and Technology (MS, South China University of Technology, China, 2010).p.47 